\title{
Comparative study of abnormalities of central nervous system in children and adults autopsied after bone marrow transplantation
}

\author{
Estudo comparativo das alterações no sistema nervoso central de crianças e adultos \\ autopsiados após transplante de medula óssea
}

Paulo R. Benites Filho'; Luis G. M. Pinto de Almeida²; José Zanis Neto33; Ricardo Pasquini ${ }^{4}$; Luiz F. Bleggi-Torres ${ }^{5}$

\begin{abstract}
key words abstract
Bone marrow

Background: We compare neuropathological abnormalities in children and adults after bone marrow transplantation (BMT) by means of autopsy in the Department of Medical Pathology, Universidade Federal

transplantation do Paraná (UFPR), Brazil. Methods: Autopsy reports of 180 patients were reviewed. They were divided

Brain diseases in two groups: patients under 15 years old and those 15 or older. Age, gender, clinical diagnosis at time Autopsy of BMT, survival time, neuropathological abnormalities and cause of death were analyzed. Results: In children (26.6\% of total) and in the adult group ( $73.4 \%$ of total), the main clinical diagnoses prior to BMT were, respectively, severe aplastic anemia (31.2\%) and chronic myeloid leukemia (36.3\%). The mean survival time for children was 102.6 days and for adults, 185.9 days after BMT. Brain lesions were considered cause of death in $20.8 \%$ of pediatric cases and $11.3 \%$ of the adult group. Neuropathological abnormalities were morphologically similar in children and adults, with the following respectively prevalence: cerebrovascular diseases in 58.3 and $56 \%(p=0.8655)$, neurotoxoplasmosis in $6.2 \%$ and $3 \%(p=0.3856)$ and infections in 27 and $25.7 \%(p=0.8489)$. Conclusions: The pediatric patients had shorter survival than adults, with increasing prevalence of neurotoxoplasmosis, and brain lesions were considered cause of death in twice as many as compared to adult patients.
\end{abstract}

\section{resumo}

Introdução: Foram comparadas as anormalidades encontradas no sistema nervoso central de adultos e crianças submetidos à autópsia após transplante de medula óssea (TMO) no Departamento de Patologia Médica da Universidade Federal do Paraná (UFPR). Métodos: Relatórios das autópsias de 180 pacientes foram revistos. Foram considerados crianças os pacientes abaixo de 15 anos; adultos, aqueles com 15 ou mais. A idade, o sexo, o diagnóstico clínico na época do TMO, o tempo de sobrevivência, as anormalidades neuropatológicas e a causa da morte foram analisados. Resultados: Nas crianças (26,6\% do total) e nos adultos (73,4\% do total) o principal diagnóstico clínico prévio ao TMO foi, respectivamente, anemia aplásica severa $(31,2 \%)$ e leucemia mielóide crônica (36,3\%). O tempo médio de sobrevivência pós-TMO para crianças foi de 102,6 dias; para os adultos, 185,9. Lesões cerebrais foram consideradas causa de morte em $20,8 \%$ dos casos pediátricos e 11,3\% do grupo adulto. As anormalidades neuropatológicas foram morfologicamente similares nas crianças e nos adultos e apresentaram, respectivamente, as seguintes prevalências: doenças cerebrovasculares em 58,3\% e 56\% ( $p=0,8655)$, neurotoxoplasmose em 6,2\% e 3\% ( $p=0,3856)$ e infecções em 27 e em $25,7 \%$ ( $p=$ 0,8489). Conclusões: As crianças tiveram sobrevida menor, maior número de casos de neurotoxoplasmose e duas vezes mais lesões graves do sistema nervoso central que o grupo adulto.

\section{unitermos}

Iransplante de medula

óssea

Patologias cerebrais

Autópsia

1. Medical resident at the Radiology Unit of Hospital de Clínicas, Universidade Federal do Paraná (UFPR)

2. Medical student and fellow at Programa Institucional de Bolsas de Iniciação Cientifica of Conselho Nacional de Desenvolvimento Científico e Tecnológico (PIBIC/CNPq), UFPR.

3. Adjunct professor at the Department of Internal Medicine, UFPR.

4. Professor and head, Bone Marrow Transplantation Unit, UFPR.

5. Professor and research fellow of CNPq, Department of Pathology, UFPR. 


\section{Introduction}

Over the past 30 years, bone marrow transplantation (BMT) as a therapeutic procedure has been used to treat several malignant diseases, genetic defects, immunodeficiency and metabolic disorders $(1,4,6,7,19)$. Advances in this field are due to progress in immunobiology, immunogenetics, cytoreduction regimen, and increase attention to the potential adverse late affects of this procedure ${ }^{(7)}$. Despite the benefits of BMT, the recipients are exposed to several potential sources of damage, including graft-versus-host disease and its treatment, toxic effects of preparative chemotherapy/radiation leading to opportunistic infections, interstitial pneumonia and venoocclusive disease $^{(1,2,4,6,7,10,12,14,19,20,23) \text {. }}$

Recent studies demonstrated neurological and neuropathological complications following $\operatorname{BMT}^{(4,6,7,20)}$. Furthermore, there seems to be an age influence in survival time after BMT, besides evidence of some specific

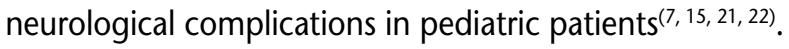

The authors present a comparative study of abnormalities of central nervous system in children and adults autopsied after BMT to confirm the eventual increased susceptibility of pediatric patients to develop central nervous system (CNS) lesions after BMT.

\section{Patients and methods}

From July 1987 to June 1998, 845 patients at our institution underwent either allogenic or autologous bone marrow transplantation. A total of 371 died and 196 were autopsied. The CNS of 180 patients was studied and their medical records were reviewed. From this amount, 177 were submitted to allogenic BMT. These patients were divided in two groups: patients under 15 years old and those 15 or older. Age, gender, clinical diagnosis at time of BMT, survival time, neuropathological abnormalities and cause of death were analyzed.

Autopsy examination was performed and brains were removed and fixed for at least three weeks in 30\% buffered formaldehyde solution. They were cut into several $1-\mathrm{cm}$ thick coronal sections and tissue samples from at least 12 different areas (frontal, temporal, occipital and parietal lobes, insula, thalamus, hypothalamus, mammilary bodies, midbrain, pons, medulla oblongata, cerebellar hemisphere and vermis) were selected. Areas in the CNS, other than the above mentioned, containing any macroscopic lesion were also sampled. Tissue sections were then prepared by routine neuropathological techniques, and additional special stains were carried out on histological sections whenever necessary. The presence of Toxoplasma gondii infection was confirmed by immunohistochemistry using polyclonal antibody (poAB) anti-Toxoplasma gondii (Biogenesis, Sandown, USA). Chi-square, Student's test and Cox-Mantel test were used for statistical analyses, and $p<$ 0.05 was defined as statistically significant.

\section{Results}

Of the 180 autopsies performed, there were 48 children ( $26.6 \%$ of total), with mean age of 9.7 years, $62.5 \%$ male $(n=30)$ and $37.5 \%(n=18)$ female. The adult group $(73.4 \%$ of total) was composed of 132 patients with mean age of 28.4 years, $63.6 \%(n=84)$ male and $36.4 \%(n=48)$ female. The distribution of gender by age is shown at Figure 1.

In the pediatric group, severe aplastic anemia (31.2\%) was the main clinical diagnosis prior to BMT, followed by Fanconi anemia (23\%), acute and chronic myelogenous leukemia $(10.4 \%)$, and lymphoblastic leukemia in $8 \%$ of the patients. Among adult patients, the most frequent underlying disorder included chronic myelogenous leukemia (36.3\%), severe aplastic anemia (30.3\%), acute myelogenous leukemia (14.3\%), and myelodysplasia in 6\% of the patients (Table 1).

Neuropathological abnormalities were found in 42 pediatric patients $(87.5 \%)$ and were subarachnoid hemorrhage $(n=15)$, intraparenchymal hemorrhage ( $n=12)$, fungal infections $(n=7)$, neurotoxoplasmosis $(n=3)$ and metabolic encephalopathy $(n=1)$. In adults abnormalities were found in $91.6 \%(n=121)$ of patients and the most frequent were: subarachnoid hemorrhage ( $n=48)$, intraparenchymal hemorrhage $(n=36)$, fungal infections $(n=9)$, metabolic encephalopathy $(n=9)$ and neurotoxoplasmosis ( $n=4)$ (Table 2). Furthermore, statistical analysis failed to show significant differences

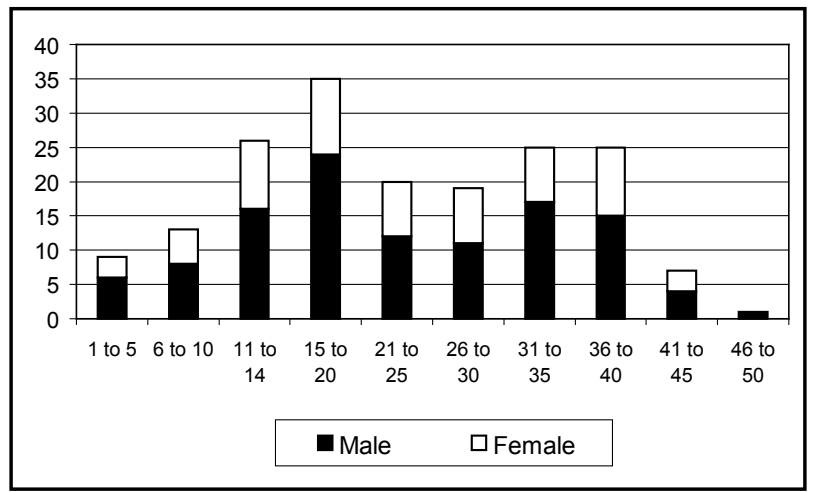

Figure 1 - Distribution of gender by age of 180 patients 
Table 1 Clinical diagnosis prior to bone marrow transplantation

\begin{tabular}{lcc}
\hline Disease & $\begin{array}{c}\text { Pediatric } \\
N^{0} \text { of patients (\%) }\end{array}$ & $\begin{array}{c}\text { Adults } \\
N^{0} \text { of patients (\%) }\end{array}$ \\
Chronic myelogenous leukemia & $5(10.4)$ & $48(36.3)$ \\
Severe aplastic anemia & $15(31.2)$ & $40(30.3)$ \\
Acute myelogenous leukemia & $5(10.4)$ & $19(14.3)$ \\
Myelodysplasia & - & $8(6)$ \\
Fanconi anemia & $11(23)$ & $5(3.7)$ \\
Acute lymphocytic leukemia & $4(8.3)$ & $5(3.7)$ \\
Other causes & $8(16.6)$ & $7(5.3)$ \\
Total & $48(100)$ & $132(100)$ \\
\hline
\end{tabular}

\section{Table 2 in BMT patients}

Summary of neuropathological findings

\begin{tabular}{lcc}
\hline \multirow{2}{*}{ Neuropathological findings } & \multicolumn{2}{c}{$n(\%)$} \\
SAH & $48(36.36)$ & $15(31.25)$ \\
IPH & $36(27.27)$ & $12(25)$ \\
Normal & $11(8.33)$ & $6(12.5)$ \\
FI & $9(6.81)$ & $7(14.58)$ \\
WE & $9(6.81)$ & $1(2.08)$ \\
NT & $4(3.03)$ & $3(6.25)$ \\
Others & $15(11.36)$ & $4(8.33)$ \\
Total & $132(100)$ & $48(100)$ \\
\hline
\end{tabular}

SAH: subarachnoid hemorrhages; IPH: intraparenchymal hemorrhages; FI: fungal infections; NT: neurotoxoplasmosis; WE: Wernicke's encephalopathy.

in fungal infections $(p=0.137)$, neurotoxoplasmosis ( $p=$ $0.3856)$, hemorrhage $(p=0.8655)$ and bacterial infections $(p=0.8499)$ in both study groups.

The mean survival time of the pediatric group after BMT was 102.6 days in comparison to 185.9 days of the adult patients $(p=0.0028)$. Brain lesions were considered cause of death in $20.8 \%$ of pediatric cases and $11.3 \%$ of the adult group $(p=0,1417)$.

\section{Discussion}

BMT contributed to therapy of life-threatening hematological malignancies, bone marrow aplasias and certain genetic and metabolic disorders. However, there are broad-ranging side effects with negative consequences for the CNS. The preparatory regimens are cytotoxic, immunosuppressive and capable of damaging many tissues, including the CNS. Delayed engraftment leads to prolonged low platelet and leukocyte counts, with risks of hemorrhage and opportunistic infections. Underlying malignant disease may not be completely eradicated by conditioning treatment and may recur despite engraftment of the new marrow $(1,2,4,6,7,10,12,14,19,20,23)$. Recent studies suggest differences among survival time, follow-up postBMT, and neurological complications concerning pediatric patients ${ }^{(7,15,22)}$. In this work, we analyzed the abnormalities of CNS in children and adults autopsied after BMT, and our results might suggest an eventual increased susceptibility of pediatric patients to develop CNS lesions after this procedure.

Cerebrovascular lesions were the most prevalent finding in our groups. Subarachnoid hemorrhage was the commonest complication, followed by intraparenchymal hemorrhage. Patchell et al. ${ }^{(21)}$ found vascular pathology in $6 \%$ of 55 autopsied patients, and in this work CNS hemorrhage was the second commonest lesion after infections. Mohrmann et al. ${ }^{(19)}$ found $26.6 \%$ of cerebrovascular lesions in 109 patients, with a mean age of 25 years, and prevalence of subarachnoid hemorrhage (17.43\%) and intraparenchymal hemorrhage (9.17\%). A variety of circumstances may have contributed to the large number of hemorrhagic complications seen in our patients. Thrombocytopenia, secondary to chemotherapy, radiation, autoimmune, or drug-induced mechanisms have also been considered major risk factors for CNS bleeding post $\mathrm{BMT}^{(9,12,18-20)}$. Furthermore, infections and coagulopathies, with secondary liver dysfunction or disseminated intravascular coagulation, have also been correlated with bleeding disorder ${ }^{(19,21)}$. Another contributory factor is the high prevalence of Fanconi anemia among our patients, since they are specially prone to subdural and subarachnoid hemorrhages ${ }^{(5)}$. A 
possible reason for this finding is the associated vascular and endothelial fragility, particularly when they are exposed to alkylating agents ${ }^{(24)}$.

Ten cases (5.5\%) of Wernickes encephalopathy (WE) were identified. The main aspects of these cases have already been discussed in a previous report ${ }^{(3)}$. WE was found in nine adult patients (6.81\%) and in just one case in the pediatric group (2.08\%). WE is characterized by a triad of altered mental status, ataxia and ophtalmoplegia, but its clinical course is usually oligosymptomatic ${ }^{(3,13)}$. All patients had nonspecific clinical symptoms, until physical symptoms of severe metabolic acidosis were detected between days +13 and +37 post BMT.

CNS infections were documented in $27 \%$ of pediatric patients and $25.7 \%$ of adults ( $p=0.8499)$, suggesting that the immunosuppressive effects involving BMT are similar in both groups. We observed an increased prevalence of fungal infections and neurotoxoplasmosis in the pediatric group. In contrast, Kusnierz-Glaz et al.(15), studying 500 patients post BMT with age ranging from 1 to 65 years, found a fourfold to fivefold higher probability of infectious complications in patients between 50 and 65 years old compared to patients between 1 and 49 years old. The main reasons for the high infection prevalence in BMT are severe neutropenia that persists for two to four weeks after the conditioning regimen and immune dysfunction due to high doses of cyclosphosphamide lasting at least for four months after transplantation. Patients with severe aplastic anemia have a higher incidence of infections than other presenting underlying diseases due to more engraftment failure, leading to longer periods of neutropenia. This could explain in part the higher incidence of infections in our pediatric group, since aplastic anemia was the most prevalent disease of this group ${ }^{(11)}$.

Toxoplasmosis is a rare but almost always fatal infection following allogeneic $\mathrm{BMT}^{(8)}$. The incidence of disseminated toxoplasmosis is 0.31 per 100 allogeneic $\mathrm{BMT}^{(16,17)}$. In the present report, we found an incidence of 1.04 per 100 allogeneic BMT and $4.44 \%$ in autopsy. These differences could be related to different endemic regions. The usual onset of symptoms is between the second and sixth months, considered to be the immunosuppressor period among BMT patients ${ }^{(17)}$. All of our patients had clinical manifestations six months after BMT. Half of toxoplasmosis patients had aplastic anemia as underlying disease, with higher prevalence in male patients, but no statistical differences between pediatric and adult group was found ( $p=0.3856$ ).

Due to recent advances in the treatment and prevention of bacterial and viral infections, fungal infections have become one of the major causes of morbidity and mortality in BMT patients ${ }^{(16)}$. In the present report, fungal infections were found in $8.33 \%(n=16)$ of the 180 analyzed brains. Furthermore, they were two times more prevalent in pediatric patients $(14.58 \%)$ compared with adults $(6.81 \%)$, but with no statistical significance $(p=0.1370)$.

\section{References}

1. ARMitAGE, J. O. Bone marrow transplantation. N Engl J Med, v. 330, n. 12, p. 827-38, 1994.

2. AUERBACH, A. D.; ROGATKO, A.; SCHRORDER-KURTH, T. M. International Fanconi Anemia Registry: relation of clinical symptoms to diepoxybutane sensitivity. Blood, v. 76, n. 2, p. 391-6, 1989.

3. BLEGGI-TORRES, L. F. et al. Iatrogenic Wernicke's encephalopathy in allogenic bone marrow transplantation: a study of eight cases. Bone Marrow Transplant, v. 20, n. 5, p. 391-5, 1997.

4. BLEGGI-TORRES, L. F. et al. Neuropathological findings after bone marrow transplantation: an autopsy study of 180 cases. Bone Marrow Transplant, v. 25, n. 3, p. 301-7, 2000.

5. BLEGGI-TORRES, L. F. et al. Intracranial hemorrhage following bone marrow transplantation: an autopsy study of 58 patients. Bone Marrow Transplant, v. 29, n. 1, p. 29-32, 2002.

6. BOMBI, J. A. et al. Main autopsy findings in bone marrow transplantation patients. Arch Pathol Lab Med, v. 111, n. 2, p. 125-30, 1987.

7. BOULAD, F.; SANDS, S.; SKLAR, C. Late complication after bone marrow transplantation in children and adolescents. Curr Probl Pediatr, v. 28, n. 9, p. 277-97, 1998.

8. CHANDRASEKAR, P. H.; MOMIM, F. Disseminated toxoplasmosis in marrow recipients: a report of three cases and review of the literature. Bone Marrow Transplant, v. 19, n. 7, p. 685-9, 1997.

9. COLOSIMO, M. et al. Diagnosis and management of subdural haematoma complicating bone marrow transplant. Bone Marrow Transplant, v. 25, n. 5, p. 549-52, 2000

10. DEEG, H. J. et al. Malignancies after bone marrow transplantation of aplastic anemia and Fanconi anemia: a joint Seattle and Paris analysis of results in 700 patients. Blood, v. 87, n. 1, p. 386-92, 1996.

11. ENGELHARD, D.; MARKS, M. I.; GOOD, R. A. Infections 
in bone marrow transplant recipients. J Pediatrics, v. 108, n. 3, p. 335-44, 1986.

12. GRAUS, F. et al. Neurologic complications of autologous and allogenic bone marrow transplantation in patients with leukemia: a comparative study. Neurology, v. 46, n. 4, p. 1004-9, 1996.

13. HARPER, C. The incidence of Wernicke's encephalopathy in Australia - a neuropathological study of 131 cases. J Neurol Neurosurg Psychiatry, v. 46, n. 7, p. 341-5, 1983.

14. KUPFER, G. M.; NÄF, D.; D'ANDREA, A. D. Molecular biology of Fanconi anemia. Hematol Oncol Clin North Am, v. 11, n. 6, p. 1045-56, 1997.

15. KUSNIER-GLAZ, C. R. et al. Influence of age on the outcome of 500 autologous bone marrow transplant procedures for hematologic malignancies. J Clin Oncol, v. 15, n. 1, p. 18-25, 1997.

16. MEDEIROS, B. C. et al. Central nervous system infections following bone marrow transplantation: an autopsy study report of 27 cases. J Hematother Stem Cell Res, v. 9, n. 4, p. 535-40, 2000.

17. MEDEIROS, B. C. et al. Disseminated toxoplasmosis after bone marrow transplantation: report of 9 cases. Transp/ Infect Dis, v. 3, n. 1, p. 24-8, 2001.

18. MEHTA, J. et al. Early identification of patients at risk of death due to infections, hemorrhage, or graft failure after allogeneic bone marrow transplantation on the basis of the leukocyte counts. Bone Marrow Transplant, v. 19, n. 4, p. 349-55, 1997.

19. MOHRMANN, R. L.; MAH, V.; VINTERS, H. $\mathrm{V}$. Neuropathologic findings after bone marrow transplantation: an autopsy study. Human Pathol, v. 21, n. 6, p. 630-9, 1990.

20. OPENSHAW, H.; SLATJIN, N. E. Neurological complication of bone marrow transplantation. In: FORMAN, S. J.; BLUME, K. G.; THOMAS, E. D. Bone Marrow Transplantation. Boston: Blackwell Scientific Inc, 1994, p. 482-96.

21. PATCHELL, R. A. et al. Neurologic complications of bone marrow transplantation. Neurology, v. 35, n. 3, p. 300-6, 1985.

22. PHIPPS, S. et al. Cognitive and academic functioning in survivors of pediatric bone marrow transplantation. J. Clin Oncol, v. 18, n. 5, p. 1004-11, 2000.

23. WIKLEE, T.; COYLE, K.; SHAPIRO, D. Bone marrow transplantation: today and tomorrow. Am J Nurs, v. 90, n. 5, p. 48-56, 1990.

24. ZANIS NETO, J. et al. Bone marrow transplantation for patients with Fanconi anemia: a study of 24 cases from a single institution. Bone Marrow Transplant, v. 15, n. 2, p. 293-8, 1995.

\begin{tabular}{l|l} 
Mailing address \\
\hline & Luiz Fernando Bleggi Torres \\
Departmento de Patologia (Neuropatologia) \\
Hospital de Clínicas - Universidade Federal do Paraná (UFPR) \\
Rua Ceneral Carneiro, 181 \\
CEP 80060-900 - Curitiba-PR \\
Tel./fax: (41) 264-1304 \\
e-mail: Ifbt@terra.com.br
\end{tabular}

